\title{
A Model of High Efficient Academic Administration for Phrapariyatidhamma School
}

\author{
Phramaha Padet Chirakulo (Jongsakulsiri) ${ }^{1}$, Phra Thersak Sattindhra (Sriwirat) ${ }^{2}$, Phramaha Woot \\ Suvuddhiko (Boonsaner) ${ }^{3}$, Phramaha Wiwat Jhanesako (Sirirat) ${ }^{4}$, Phramaha Suwat Suwatdhano \\ (Senpeng) ${ }^{5}$ \\ ${ }^{1}$ Dhammakaya Open University, \\ ${ }^{2,3,4,5}$ Faculty of Education, Mahachulalongkornrajavidyalaya University \\ 1 padet.jong@mcu.ac.th, ${ }^{2}$ mawo919@gmail.com, ${ }^{3}$ phrawoot072@gmail.com, ${ }^{4}$ chanespiero10@gmail.com, \\ ${ }^{5}$ sususu0072@gmail.com
}

\begin{abstract}
The purposes of this research were 1) to study the state of area, high efficient academic administration of Phrapariyattidhamma school, 2) to develop and propose the high efficient academic administration of Phrapariyattidhamma school. The mixed research methods; quantitative research and quantitative research were used and research tools were interview form and questionnaires. Results indicated that 1) the status of academic administration in Phrapariyattidhamma schools, was at a high appropriate level in 5 aspects. 2) In development of high efficient academic administration, personnel consisting of administrators, teachers, staffs and student must be developed in 6 aspects: 1) The curriculum must be continuously adjusted according to community contexts. 2) A new body of knowledge must be created in teaching and learning system. 3) Media and instruments must be up-to-date and can be accessed unlimitedly. 4) Teachers and staffs must create teaching innovation and generate the knowledge to community. 5) Learning area must cover academic, career training and ways to live a life for every level of people. 6) Learning sources must support physical, mental, moral and ethical values of society. The form of high efficient academic administration consisted of 5 aspects in academic administration and 6 aspects of high efficient qualification as 5A 6Q Model.
\end{abstract}

Index Terms

High Efficient, Administration, Phrapariyattidhamma Schools

Article Received: 10 August 2020, Revised: 25 October 2020, Accepted: 18 November 2020

\section{Introduction}

Educational management aims to develop people in the country to learn and keep pace with the changes of society and the world. Therefore, the ministry of education has a policy aimed at developing the people of the nation. To grow the whole body and the mind without socialization, and monks and novices, nuns are a group that must be developed in education to be effective. Have knowledge of both secular and religious traditions; and able to spread Buddhism to progress and also beneficial to the government, that is if a monk and a novice leave the Buddhist monkhood able to study in public educational institutions or being able to continue living in the practice of living that is beneficial to oneself and the country.

Therefore, Phrapariyattidhamma school department of General Education. It was established due to the establishment of Bali Secondary Education School and Bali Extraordinary Education of the two monastic universities, Mahachulalongkornrajavidyalaya University and Mahamakut Buddhist University which has been in operation since 1889 and 1946, respectively. Later, Mahachulalongkornrajavidyalaya organized a secondary education department called "Bali Secondary School" when the Bali Secondary School was widespread. The Sangha by the educational organization. Therefore, this type of school was called "Bali Extraordinary Education School for Students" by the Sangha. Then the Ministry of Education issued a regulation, the Ministry of Education since 1957. Study of the dharma the new Pali department was called
"Pali for Ordinary and Periyat Education" and abolished the Sangkhamor Regulations on Education of the Pali Extraordinary Education for students. Later considered that Secular education thrives advance more according to the changing conditions of the world. Therefore, to see that there should be a school General Education Department in order for the students to practice themselves for both secular and moral benefits at the same time. Therefore, it has a regulation of the Ministry of Education on Phrapariyatidhamma School Department of General Education on July 20, B.E.2514, supports and regulations of the Ministry of Education on Phrapariyatidhamma School Department of General Education, Year 1992.

According to the Ministry of Education Regulations on Phrapariyattidhamma School Department of General Education Year B.E.2535 stipulated that the school Phrapariyatidharma Department of General Education refers to schools established in the temple. Or at the monk or the land of the Buddhist Foundation to educate monks and novices according to the curriculum of the Ministry of Education for Phrapariyattidhamma School, The Department of Education can be established only with permission from the Ministry of Education. And with the approval of the President of the Sangha Education Council. The school must provide instruction according to the Ministry's curriculum Education by the National Buddhism Office will provide support as a subsidy according to the budget and in accordance with the criteria set by the Educational Committee of Phrapariyattidhamma School Department of General Education. 
Therefore, Phrapariyattidhamma School Department of General Education is the provision of basic education. Which is a systematic study along with the management of dhamma education in both the Pali and dhamma departments for monks and novices. By accepting boys who graduated from grade 6 and ordained as a monk novice to continue their secondary education Phrapariyattidhamma School. The General Education Department was established by a Buddhist temple. There is a temple abbot who requested the establishment conducted by teachers who are both monks and laymen.

From the background study it was found that the establishment of the Phrapariyattidhamma School Department of General Education. It was established from the cooperation between the Sangha Association and the Ministry of Education for the development of educational quality of the novice monks to have knowledge and experience that are in line with the changes of society and modern science to make the learner a successor to Buddhism or a quality population of society and provides opportunities for economically and socially disadvantaged children such as families to live in poor rural areas. There are no funds to study. Residing in a remote area of prosperity unable to attend normal public school. Give the children of those people the opportunity to come to study to develop knowledge to develop social status and to be good in society.

However, the status quo of the management of Dhamma education Department of General Education, there are many important development issues. Issues of quality and standards in the present education of Phrapariyattidhamma School Department of general education that is not yet recognized by the broader society. The ambiguity in the identity of the educational arrangement is truly consistent with the context it should be. The efficiency of the system of administration and education management that has not yet developed direction and lack of clarity in building administrative unity of school groups and provincial Buddhist offices. It was also found that the creation of covenants, operations and the provision of education for the creation of a coherent heiress was not set to be concrete.

Administration of Phrapariyattidhamma School the general education department still encountered many problems and obstacles, namely the personnel side, it was found that there was a lack of qualified and qualified teachers. As for the building, there is also a school of Phrapariyattidhamma about half of the general education department does not have its own school building. Including the school administration problem is not as efficient as it should. And also found that Phrapariyattidhamma School the general education department has no permanent personnel. Teachers are only temporarily hired, which causes frequent switching problems. Low morale and morale the lack of teaching and learning equipment was not supported as expected. This was consistent with the research of Phra Anukul Worakan Phasukkamo found that the academic administration problem was at a moderate level. When considered individually, it was found that there were two criteria with high averages: school curriculum development was inconsistent with local communities. And the implementation of local curriculum in teaching and administration that is inconsistent with the core curriculum.
Teaching management at Phrapariyattidhamma School there is a decrease in the number of students enrolled. This could be caused by many reasons, such as monks and novices have more opportunities to attend other educational institutions, lack of motivation to attend. And those who attend the Phrapariyattidhamma School the general education department can take the competitive examinations to enter the educational institutions with a very small number of national voices, etc., which are all caused by inefficient academic administration problems. From such circumstances in order to provide academic management to meet the quality standards that will result in the education of the Buddha so effective it needs to be managed seriously and correctly according to the principles of academic administration. Both in the course the process of learning innovative media and technology for measurement and evaluation educational supervision. Including educational quality assurance which provides education in various fields. These are all ways to develop high-performance academic work for Phrapariyattidhamma School to grow with quality and meet more standards.

From its primary importance this makes the researcher interested in studying a high-performance educational institution administration model for Phrapariyattidhamma School. To guide the framework for the administration of Phra Pariyatidhamma School taking into account the opportunity to spread Buddhism and build a knowledgeable heir. The ability to manage the Phrapariyattidhamma school to keep up with the changes of society.

\section{Research Objectives}

The objectives of this research article were 1) to study the state of area, high efficient academic administration of Phrapariyattidhamma school, 2) to develop and propose the high efficient academic administration of Phrapariyatti dhamma school.

\section{Research Methods}

The researcher conducted a mixed method research by analyzing data from review literature such as documents, textbooks, statistical data, research reports. Reports from various departments, academic articles, dissertations, as well as research related both domestically and internationally and in-depth interview formally. By interviewing the researcher to study the opinion of school administrators the target group is the case study, the researcher has determined the methodology, research methodology in the following steps.

Step 1: Study the state of area, high efficient academic administration of Phrapariyattidhamma school by 1) studying textbooks, academic papers, online media and related research, and 2) interviewing key informants in the form of 15 persons by purposive selection.

Step 2: Develop the high efficient academic administration of Phrapariyattidhamma school by focus group discussion 10 key informants / person with purposive selection.

Step 3. Examine and present the forms of the high efficient academic administration of Phrapariyattidhamma school. 1) checked by answering quantitative assessment forms. 2) edit, improve and present the form of the high efficient academic administration of Phrapariyattidhamma school. 


\section{Results}

\section{Document analysis results}

The results of the analysis of documents regarding the circumstance/condition of the high efficient academic administration of Phrapariyattidhamma school. Can be summarized as follows

1. State of the 5 Phra Pariyatidhamma School Administration.

1.1 For the curriculum, it was found that the administrators and teachers summarized the results of the curriculum management continuously. Continuous monitoring and evaluation of course management. Create an educational institution curriculum from the core curriculum study.

1.2 On the learning process, it was found that the administrators and teachers emphasized the students to take action. Organize content and activities taking into account individual differences. Encourage learners to develop analytical thinking processes.

1.3 Innovation media and educational technology, it was found that administrators and teachers adopted modern technology improve technology materials to be ready for each academic year. Appropriate to the current social situation.

1.4 In terms of educational measurement and evaluation, it was found that administrators and teachers organized an information system for measuring and evaluating learning results up to date. Evaluate and evaluate the actual results of the learners' learning behavior. Establish clear rules and guidelines.

1.5 In terms of educational quality assurance, it was found that administrators and teachers developed a quality development plan for educational institutions. Schools pay attention to this matter. Appoint an operating committee.

2. The standard for promoting the organization to have high competency for the 6 Phrapriyattidam schools found that:

2.1 The Ability of the organization to change, including creating a new structure with an emphasis on the use of teams and organizations without borders. There is a greater loyalty to the organization. The organization has highly qualified and educated administrators and teachers.

2.2 The Creation of new knowledge widely, including allowing the learners to perform self-learning activities. Place the learner as the center of learning learners use technology as a tool for learning to seek answers from various knowledge sources themselves.

2.3 Organization without borders: administrators and teachers can fully utilize their potential. Administrators and teachers can work in diverse teams. The school has information on information technology to create organizations without borders.

2.4 To Motivate personnel to achieve high performance, schools have needs to motivate personnel to achieve high performance. Management looks at people from internal motivations based on their attitudes towards the school and their special interests. Schools have the temptation or goal to motivate people to achieve high results.

2.5 To be a great place to work: administrators and teachers organize classrooms and the building to learn. Together to work as a team happily Schools have the temptation or goal to motivate people to achieve high results. Administrators and teachers create a positive attitude towards teaching and learning.

2.6 Organization that emphasizes value, namely administrators and teachers honest and virtuous towards colleagues follow the regulations internal and external audit processes, and use the maximum potential of the individual in performing the job with uncompromising goals for excellence.

Which the research results are consistent with the research of Phramaha Kraiwan Punkhan has studied. The results of the study showed that:

1. The strategic leadership component of the administrators of the Phrapariyatti dhamma school administrators. It consists of 5 elements: 1) strategic planning 2) leadership 3) vision 4) morality and ethics 5) organizational management

2. Strategic leadership style it is a model that consists of 5 essential elements that are feasible, correct, appropriate and can be utilized. Consistent with the theoretical framework of the research.

In accordance with Kanyarat Muang Song that has studied "Strategic Leadership Development Model for Basic Education Administrators" using Delphi techniques in data analysis. The study found that "The Strategic Leadership Development Model for Basic Educational Institution Administrators Based on Expert Thinking consists of Component 1: having a high level of cognitive activity, the ability to think analytically. Which can distinguish various elements of one thing. Component 2: is capable of collecting various information to define strategies, such as planning and project results are reported to be used as information for the development of work and to formulate action plans. Component 3: Ability to predict and determine the future, i.e. capable of being proactive in solving problems urgently. While most executives will analyze the situation first. And waiting for the problem to be resolved by itself. Complement 4: Revolutionary thinking includes allowing the community to take part in setting up school policy. Element 5: The vision is defined, including the inspired vision. Ambitious, out-of-the-box thinking, and the top three selected strategic leadership development methods are study visits. Academic conference and brainstorming as for the concept of the basic education institution administrators, it was found that the key issues according to the five components were Component 1: namely the promotion of personnel to develop themselves and profession for the quality of education. Component 2: is to have a goal of work and happiness in work. Component 3 : is a strategic planner. Driving strategies and thinking proactively. The fourth component is proactive thinking and inspiring colleagues to take initiative in their work. And problem solving and the fifth component is to clearly define the vision in accordance with the changes of society Current situation and strategic goals for the government sector.

3. Results of the study on the Development of High Performance Models for Phrapariyattidhamma School. Development of high-performance models for the 5 areas of Phrapariyattidhamma: 1) the curriculum, 2) the learning process, 3) the innovative media and educational technology, 4) the evaluation and evaluation of education, and 5) the quality assurance of education study the following. 
3.1 Ability of the organization to change promote by budgeting to support personnel establish a working network through information technology promote personnel to have knowledge both in the world and in the wrong way.

3.2 The Creation of new knowledge widely promote by organizing activities to promote learning with a studentcentered emphasis. Teachers and Students learn, invent, analyze together, and connecting new and old knowledge to face the outside world.

3.3 The Creation of an organization without borders promote the school development plan every year. Establish knowledge-based personnel and create a shared learning network through parents, teachers and students.

3.4 To Motivate personnel to achieve high performance. Promoted by administrators, having Buddhist principles, setting goals according to the school policy and stimulate desire through temptation.

3.5 To Be a great workplace promote by organizing the place to be a "Sappaya". Create a collaborative environment and create a positive attitude to work.

3.6 As a value-based organization people in the organization must be honest and respect each other. And work together as a team.

Consistent with the research of Kanyarat Muangsong has studied "Strategic Leadership Development Model for Basic Education Administrators" using Delphi techniques in data analysis. The study found that "The Strategic Leadership Development Model for Basic Educational Institution Administrators Based on Expert Thinking consists of component 1 , having a high level of cognitive activity, ie, the ability to think analytically. Which can distinguish various elements of one thing. Component 2 is capable of collecting various information to define strategies, such as planning and project results are reported to be used as information for the development of work and to formulate action plans. Component 3: Ability to predict and determine the future such as capable of being proactive in solving problems urgently. While most executives will analyze the situation first. And waiting for the problem to be resolved by itself. Complement 4: Revolutionary thinking includes allowing the community to take part in setting up school policy. Element 5: The vision is defined, including the inspired vision. Ambitious, out-of-the-box thinking, and the top three selected strategic leadership development methods are study visits. Academic conference and brainstorming as for the concept of the basic education institution administrators, it was found that the key issues according to the five components were component 1 , namely the promotion of personnel to develop themselves and profession for the quality of education. Component 2 is to have a goal of work and happiness in work. Component 3 is a strategic planner. Driving strategies and thinking proactively the fourth component is proactive thinking and inspiring colleagues to take initiative in their work and problem solving and the fifth component is to clearly define the vision in accordance with the changes of society current situation and strategic goals for the government sector.

4. The high-performance educational institution administration model for Phrapariyattidhamma School consists of:

Academic Management Development to have high performance with the development of personnel, namely administrators, teachers, staff and students in the school development to have high competencies.

$5 \mathrm{~A}=5$ Administration, including curriculum administration, learning process, educational media, innovation and technology, education evaluation, and education quality assurance.

$6 \mathrm{Q}=6$ Quality, including 6 features:

1) has changed educational curriculum that is aligned with the community continuously.

2) create new academic knowledge in teaching and learning management.

3) able to teach by media advanced equipment searching without borders.

4) personnel, teachers and creative staff can contribute to teaching and educating communities at a higher level.

5 ) it is a great place to learn both academic, professional and lifestyle for people of all levels.

6) give both physical and imaginary values with moral value Ethics for society.

\section{Recommendations}

\section{A. Recommendations for Practices}

1. The Government sector and related agencies in Phrapariyattidhamma School, General Education Department should support the budget for the administration of Phrapariyattidhamma School.

2. Government sector and related agencies should support the development of educational personnel for Phrapariyattidhamma School.

3. The Government sector and related agencies should promote the teaching and learning media to be up to date and sufficient to meet the needs of Phrapariyattidhamma School.

\section{B. Recommendations for Further Research}

Because of the research on the issue of academic administration, Phrapariyattidhamma School, High Performance Education Department, setting up environment conducive to academic administration. Research should be conducted on the issue of academic administration at Phrapariyattidhamma School, General Education Department in Thailand, in academic development promoting learning through technology. There should be research on the issue of approaches to development or academic administration strategies of Phrapariyattidhamma School, General Department, organizing learning promotion activities with a learner-centered emphasis.

\section{Conclusion}

In Conclusion, the findings from the analysis of both quantitative and qualitative showed that from the study of the concepts, theories, Academic Management Development to have high performance with the development of personnel, namely administrators, teachers, staff and students to qualify according to the principle of high competence in school development, namely 5 courses, learning processes, media, innovation and educational 
technology. The evaluation and evaluation of education. Education quality assurance with 6 features: 1) Changes Educational curriculum that is aligned with the community continuously, 2) Create new academic knowledge In teaching and learning management, 3) Able to teach by means of media advanced equipment search without borders, 4) Teachers and creative staff can work on teaching and educating communities at a higher level, 5) To be a great place to learn both academic, professional and lifestyle for people of all levels, and 6) Give both physical and imaginary values with moral value ethics for society with support and promotion from the principles of Buddhism in the work.

\section{References}

[1] K. Muangsong. "Strategic Leadership Development Model for Basic Education Administrators". Doctor of Education Thesis. Education Administration Branch Graduate School: Burapha University, 2007.

[2] Phramaha Kraiwan Punkhan, "Strategic Leader of the School Administrators of Phra Pariyatidhamma". Doctor of Philosophy Dissertation Education Administration Branch Graduate School: Silpakorn University, 2009.

[3] P. Nukroh and others, "Sangha Education and Educational Reform under the National Education Act B.E. 2542". Academic Dialogue Report, Bangkok: Pimdee Printing Co., Ltd., 2001.

[4] https://th.wikipedia.org/wiki: Coming from the National Buddhism Office. Information for academic year 2016, retrieved on November 4, 2020. 